\title{
WATER-ECONOMIC PROBLEMS IN NORTHEASTERN MONTENEGRO
}

\author{
Goran Rajović, Ph.D. \\ Street Vojvode Stepe 252, Belgrade, Serbia \\ E-mail: dkgoran.rajovic@gmail.com, Phone: 0038161/19-24-850 \\ Jelisavka Bulatović, Researcher \\ College of Textile Design, Technology and Management \\ Street Starine Novaka 20, Belgrade, Serbia \\ E-mail: jelisavka.bulatovic@gmail.com, Phone: 003861/ 3082651
}

\begin{abstract}
The paper discusses the problems of water economic northeastern Montenegro municipalities Berane, Andrijevica and Plav. It points to the problem of exploitation of water, protection of water and water protection. Within exploit water resources, the possibilities of water supply of population and industry, water supply, agriculture, hydropower exploitation, tourism and recreational use. Current and future use of water resources considered GeoScape, requires a new approach, which should be in accordance with the concept of active protection of the environment.
\end{abstract}

\section{KEY WORDS}

Northeastern Montenegro; Water; Population; Industry; Agriculture; Water supply; Hydropower; Tourism and recreational use; Environmental protection.

Northeastern Montenegro is a geographical unit, which comprises $10.8 \%$ of the total area of Montenegro (13.812 $\left.\mathrm{km}^{2}\right)$, or living in the territory, $8.12 \%$ of the population compared to the total population of Montenegro in 2003 (673.094). In terms of administrative-territorial belonging, territory covers three municipalities of Plav, Andrijevica and Berane. The total area of the considered geographic space is $1.486 \mathrm{~km}^{2}$. According to are census of 2003 in three urban areas (Berane, Andrijevica, Plav), small town (Gusinje) and 109 rural settlements lived 54.658 inhabitants or $36.8 \mathrm{in} / \mathrm{km}^{2}$ (Rajović and Bulatović, 2013).

Water resources of northeast Montenegro are important and diverse. The greatest are economic value has released and springs rivers and lakes. Diversity and complementarily of water resources is the main characteristic of the considered geographic space, which is of particular importance for the future economic development of the region. Of course, no matter how much water potentials of this part of northeastern Montenegro were great; they are not unlimited and inexhaustible. Therefore, their use must be planned and rational. Starting from the classification of natural resources Dinić (1981) and Ghosh (2011) we tried to find answers too many water management issues. Therefore, we devised our own theoretical premises from which we started with the goal of defining and understanding the water potential of geo considered in the context of its use and exploitation. Accepting such a criterion, we impose the need to consider concluding instead, point out the concept of active protection of the environment.

\section{RESEARCH METHODOLOGY}

Two main groups of data sources used in the study. In the first group, including sources of data on water supply of population and industry are available from the Secretariat of Economy Municipal Assembly Berane, Andrijevica and Plav. The second group of data makes the results of previous studies, published in both domestic and international in literature. Study of are written sources on the Internet. The focus of the research based on an analysis of hydrologic problems in northeastern Montenegro. Is scientific explanation of terms, by two methods: analytic and synthetic. Analytical method, were considered certain economic and geographic dimensions of the case studies. Since work has essentially synthetic character, used the results published in the international literature. Among them, this time emphasizes this: Grafton et al (2010), Boberg (2005), Barbour (1970), Coelli and Walding (2006), Covalla et al (2001), Williams and Shaw (2009), Thévenon (2002), Palanti et 
al (2011). For more complex understanding of water management issues was necessary and the application of the concept of interdisciplinary study, which was based on the methods and results of other scientific disciplines: economics, agriculture, tourism, hydrology ...

\section{ANALYSIS AND DISCUSSION}

Water problems. Water resources issues referred to in the broadest sense of the word: the problems of exploitation of water, protection of water and water protection.

Use of waters. In this issue, we are looking at the possibilities: municipal and industrial water supply, agricultural water supply, hydropower exploitation and tourist - recreational use.

Water supply population and industry. The problem of water supply of population and industry usually solved together. Water supply Berane Andrijevica and Plav in a modern way began in the early sixties. In doing so, they generally stronger capped karstic springs. Berane water supply as a regional center of the northeastern part of Montenegro, dedicated to the most attention because of population growth and industrial development. The construction of urban water supply in Berane began in 1962 and this regulation "the Monastery springs" whose capacity was $85 \mathrm{l} / \mathrm{s}$. Today it serves as a backup source of water supply for the urban part of Berane. Since 1989, the urban part water supply Berane and suburban areas carried out in water Lubnice - Berane, which supplied with water from the catchment 'Merića fountainhead. "Latest estimates Public Enterprise "Water and Sewerage" - Berane, indicating that the flow of water through the main pipeline from the spring to the breaking chamber about $190 \mathrm{l} / \mathrm{s}$ (www.berane.me). Length of distribution network (primary and secondary) is $160 \mathrm{~km}$ long and covers about $70 \%$ of the municipal territory, and uses about $65 \%$ of Berane. "Pumping water is done by gravity and pressure inlet tube with two initial stations. Annual turnover of water billed to customers 75.000" (www.nasme.me). Rural part of Berane Polica, Upper Budimlja, Dapsiće, Petnjik supplied with water from "Hot Dapsiće" with a capacity of $49 \mathrm{l} / \mathrm{s}$. Expanding the water network and the increasing number of consumers, and caused an increase in the production of water. Thus, according to the Municipal Secretariat for Economy Berane Municipal Assembly, the motion and structure of water consumption can best seen from the data just follow. The per capita water consumption in 1975 was Berane $0.31 / 10^{6} / \mathrm{m}^{3}, 19851.21 / 10^{6} / \mathrm{m}^{3}, 19911.91 / 10^{6} / \mathrm{m}^{3}$. If are calculated average in $\mathrm{m}^{3} / \mathrm{d}$, then it was 0.003 in 19750.006 in 1985. and 0.01 in 1991. On the other hand, the water consumption in the industry ranged from $1.07 / 10^{6} / \mathrm{m}^{3}$ in $1975,1.16 / 10^{6} / \mathrm{m}^{3}$ in 1985 and $1.80 / 10^{6} / \mathrm{m}^{3}$ in 1991 . In the mentioned period, total water use in Berane for population and industry, were $1.38 / 10^{6} / \mathrm{m}^{3}$ in $1975,2.37 / 10^{6} / \mathrm{m}^{3}$ in 1985 and $3.75 / 10^{6} / \mathrm{m}^{3}$ in 1991 . According to data from the Municipal Secretariat for Economy Berane Municipal Assembly in 2000, the total need for water Berane amounted to 5.62 million $\mathrm{m}^{3}$, of which for two people, 96 million $\mathrm{m}^{3}$ and 2.66 million- $\mathrm{m}^{3}$ industry.

Plav, the second largest city and industrial center of the second part of northeastern Montenegro, has a dense network, but not abundant karst springs and wells, which reduces the possibility of its permanent supply of drinking water. For now, supplied with water from springs and aquifers ("Đurički alluvion of the River"), with an average yield (15 l/s), less than the total needs. The Plav feels chronic water shortages in the summer period, particularly in rural locations and Gusinje -Murino. Insufficient water supply of the population followed by many other rural towns: Prnjavor, Brezojevice, Kruševo, Martinovići ... It is important to emphasize at this point that the water pipes in the Plav obsolete and made of asbestos (main lines - profile of $200 \mathrm{~mm}$ and $110 \mathrm{~mm}$ ) and plastic - other lines. This circumstance causes huge losses in the network, which estimated at more than half the amount of water transported in the pipeline. Length of the water is about $5.2 \mathrm{~km}$, profiles 300 and $280 \mathrm{~mm}$, the primary distribution line is a distance of about $5 \mathrm{~km}$, and the total length of the secondary network is about $10 \mathrm{~km}$. In Gusinje is also plumbing, plastic pipes overall length of $6.5 \mathrm{~km}$. Primary local area network made of asbestos with a length of about $4 \mathrm{~km}$ and profiles 150 and $100 \mathrm{~mm}$, and a secondary plastic pipe length of about $6 \mathrm{~km}$. In Murino identical supply pipeline built of plastic, with a total length of $5.5 \mathrm{~km}$ in length, and a local network length is about $2 \mathrm{~km}$ and derived from plastic pipes (www.nasme.me). According to the Secretariat of Economy of the Municipality Plav, water consumption in 1991, Plav was 3.05 million $\mathrm{m}^{3}$, of 
which the industry consumed 1.18 million $\mathrm{m}^{3}$, and the population of 1.87 million $\mathrm{m}^{3}$, i.e. $61.31 \%$ of the total. Total needs for Plav Water in 2000 amounted to 3.97 million $^{3}$, of which the needs of the population are $1 / 2$ of the overall needs; it is 1.99 -million $\mathrm{m}^{3}$ and 1.98 million$\mathrm{m}^{3}$ industry.

Andrijevica is less urban and industrial center of the northeastern part of Montenegro. The first water system for organized water supply built in 1931 , with a capacity of $0.3 \mathrm{l} / \mathrm{s}$. At the end of the eighties, "Water economy organization for the development and utilization of water of Montenegro" - Podgorica did a "Major water project for Andrijevica", taking into account the then current situation and future social and economic development of urban settlements, with the immediate environment, which includes rural areas: Andželati, Božići, Bojovići, Đulići, Kralje, Prisoja, Seoce and Slatina. Water supply started in 1982 on the organization of springs "Krkori". Projected water system built: buildings at the source "Krkori" water pipeline constructed of cast- iron pipe diameter of $300 \mathrm{~mm}$. The terms of reference for the development of "Water main reconstruction project" envisaged that this iron-cast tubes do not replace, but only to replace asbestos cement pipes, the use of which by European standards is no longer allowed (www.nasme.me). After the road Andrijevica - Cecuni - Kuti in 1984, made amendments to the "Main Project" which is performed by the current water supply system, which relates to revise previously constructed road route over the pass "Pear". Finally, in the "Project of reconstruction of water" source "Krkori" - Andrijevica projected for the second time, by the route of the pipeline related correction to improve the hydraulic conditions in the "management" of water, and that part of the route to moved on its part that is accessible along the road to the well "Krkori". So today, in addition to urban settlements Andrijevica, from are water supply and rural: Đuliće, Bojoviće, Seoce, Božiće, Prisoja, Slatina, Zabrđe and Trešnjevo (www.andrijevica.me). According to the Secretariat of Economy of the Municipality Andrijevica, total water consumption in 1991 amounted to 2.06 million $\mathrm{m} 3$, of which the industry consumed 0.26 million $\mathrm{m} 3$, and the population of 1.8 million m3.

Agricultural water supply. Irrigation involves bringing water into the soil, the period when crops need, and the soil is not sufficiently (Ćirić, 1991). From the amount of precipitation in the northeastern, part of Montenegro, in terms of agricultural production, points to the necessity of irrigating during the months of July and August, when the hydrothermal coefficient values below unity. As an indicator of insufficient amounts of moisture can taken hydrothermal stripping ratio, calculated by are method Seljaninova. "Conditional soil moisture balance is equal to ten times the quotient of the amount of rainfall in the growing season and temperature sums this period. By this method, hydrothermal coefficient of less than 1 indicates a lack of moisture, while values between 3 and 4 show the redundancy of moisture"( Đukanović, 1967). Plav is stripping ratio of 0,9, in Berane and Andrijevica 1,3, pointing to the lack of moisture and the need for irrigation. When these parameters are brought in connection with the drought index, it follows that the July and August, the months in which the necessary irrigation of agricultural areas ( Rajović, $2013 \mathrm{a}$ ). Benefits for irrigating the observed geographic space are different. Flies are primarily available water, quality land types and morph metric predisposition. Therefore, the use of river water for irrigation in the northeastern part of Montenegro, in time and space is limited. The striking discrepancy between the amount of available river water and the required amount of water for irrigation, tied for July and August. So Plav at the station, Lim has a mean monthly flow of $13.7 \mathrm{~m}^{3} / \mathrm{s}$ (July), $6.8 \mathrm{~m}^{3} / \mathrm{s}$ (August), and the station Berane $20.8 \mathrm{~m}^{3} / \mathrm{s}$ (July) and $11.4 \mathrm{~m}^{3} / \mathrm{s}$ (August). During the summer months (July, August, September), during the lapse of the river $9-12 \%$ of the annual flow, which is near Plav $17.8 \mathrm{~m}^{3} / \mathrm{s}$, and near Berane $37.4 \mathrm{~m}^{3} / \mathrm{s}$ ( Rajović, 2005). In addition, many of the rivers in this period are below the biological minimum flow, and a deficit of irrigation water more pronounced. However, most of the streams in the northeastern part of Montenegro, no hydrological observations and measurements, generalizations would not give useful results. To say balance the flow of the river Lim, it is necessary to reduce surface runoff and the longer you hold the groundwater in the basin. The use of different agricultural practices (improving vegetative cover, deep plowing, plowing on contour lines), and the construction of reservoirs in limited geographic space, to provide additional water for irrigation, and balance the flow of ground water regime. By moving riverbeds, flood and sand spreading alluvial plains along major rivers accumulate 
unproductive gravelly-sandy deposits, and by the time of high water intensifies Lima infiltration river water to alluvial deposits, thereby creating damp and waterlogged soil. Areas flooded alluvial plains covered with forest vegetation and sterile deposits that occur between the riverbanks.

In relation to morph metric analysis relief benefits, the most favorable conditions for irrigation have alluvial valleys Berane, Andrijevica and Polimlje. In hilly terrain in the hills Berane depression, Valley Andrijevica, Polimlje and Plav-Gusinje basin, they complicated by the increased slope and higher hypsometric position in relation to the bed of Lima. Artificial reservoirs for irrigation in the northeastern part of Montenegro, to built on tributaries of Lima, and that without blue large complexes of arable land. Special benefit the construction of reservoirs on tributaries of Lima is contained in their hypsometric favorable position in relation to arable land at the bottom of Valley Berane, Andrijevica, Polimlje and Plav-Gusinje basin. Advantageous morphological, geological and climate conditions for the construction of reservoirs related to the mean flow of the river and the hilly and mountainous valley rim.

From these reservoirs can be irrigation of agricultural lands naturally (gravity), since they have a higher hypsometric position in relation to the arable land in the alluvial plain. Optimal opportunities to build reservoirs valleys provide Ljuče and Komorače. Channel network of reservoirs in these flows could easily usher along Plav-Gusinje basin. For downstream basins should consider in the formation of small reservoirs: Zlorečica, Bistrica and Lješnica. Therefore, water management solutions should sought within the Spatial Plan of Montenegro, which refers to that part of, water management and water laws, where it is necessary to set the focus on the construction of the regional water supply, irrigation and drainage, and of course the aforementioned accumulation.

The most common form of irrigated farmland in is northeastern part of Montenegro now performed by collecting water from the aquifer. Irrigation done is primitive, although increasingly used motor pumps for pumping water out of the water intake. However, this water could use as comprehensive. The basic problem, which requires you to consider the possibility of organizational irrigating considered geographic space, related to the small subdivision of property. The average size of private farms is 6.19 ha. However, if one takes into account the farmland, then the average size of private farms decreased to 2.91 ha ( Rajović, 2013b). This limit comes from the sphere of social relations, and not the specific characteristics of the natural resources. In other words, consolidation is a necessary condition for the functioning of the economic system melioration.

However, the problem of water supply most complicated of high karst terrain. It should provide drinking water for livestock reclamation of natural pastures and meadows in order to achieve high yields of hay. The problem of securing the necessary amount of water in this part of northeastern Montenegro is one of the causes of fading livestock and certainly the most important factor of neglect karst terrain in the economic development of the municipalities Berane, Andrijevica and Plav.

Accurately establishing is required amount of water for irrigation not performed. According to data from 1998 in this part of northeastern Montenegro, 29.787 ha of arable land irrigated only about 1.000 ha of arable land. To irrigate small plots of vegetables and water to wells or water from are riverbeds. Most irrigated by surface is in Berane valley 550 ha.

Thus, compared to the deficit of atmospheric moisture on are fields, the percentage of irrigated farmland symbolic. Thus, the considerable area, crops are exposed to drought reduces total available agro-ecological potential of geo considered. A forestation and grassing parts of river threatened by erosion, construction of reservoirs, channel regulation and proper use of land with steeper, balances of inland river regime and reduce the risk of flooding. Effective measures of flood control levees along the riverbed and Lima.

Hydro-energy exploitation. In 1956/57 group of experts "Energy-project"from Belgrade drafted are report "Study of accumulation Plav". It provides hydro-energy use of Basin Water Lake with three variants of the rise of water (elevation $945 \mathrm{~m}, 933 \mathrm{~m}, 917 \mathrm{~m}$ ) and with a dam Gradac hill, not far from the exit Lima from Lake. All three versions provide full immersion not only Plav Lake Valley but also angry. The projected hydropowers "Plav" is a $24 \mathrm{MW}$, and would mean are first of 11-planned hydroelectric Lim (www.beranetown.nen). According to data from the Regional Business Center Berane (www.nasme.me), which refers to "the study 
of energy use and its tributaries Lima" only in Plav, it is possible to build 15-hydropower formidable strength of $42.595 \mathrm{MW}$. Several power plants would have a very good performance in terms of power, potential, and the annual cost per $\mathrm{KW} / \mathrm{h}$. For example, hydropower "Jara" on River Komarača say is most interesting because it has the following characteristics: an installed capacity of $6.8 \mathrm{MW}$, installed flow $3.85 \mathrm{~m} / \mathrm{s}$, waterfall the $220 \mathrm{~m}$, annual output of energy $21.57 \mathrm{GWh}$. The project envisages the construction time of one year, with the length of the inlet pipe was $4.1 \mathrm{~km}$, length $570 \mathrm{~m}$ steel pipe with a diameter of $0.8 \mathrm{mi}$ final prices $\mathrm{KW} / \mathrm{h}$. So hydro "Jara" according to the study mentioned above, constitute by far the cheapest hydroelectric power plant in the former Yugoslavia. In conclusion, in this part of northeastern Montenegro to the present day, there is not a power plant, even though there are more on Lim suitable place for their construction.

Tourist-recreational use. Water potential for tourism and recreational purposes in the northeastern part of Montenegro is quite modest. The forms of recreational water use reduced to fishing and swimming in rivers and lakes. Terms of thermal conditions during the summer months in the immediate valley of Lima, recreation room on the rivers is attractive, both for the local population, as well as in relation to the transit tourism. The specificity of environmental features along is riverbanks determined by the increase in relative humidity, Tosca winds, and shady forests hydrophilic.... In relation to the needs of transit tourism sector is particularly attractive flow Lima through valley Berane, Andrijevica where the visitors made breaks in places that have the best position in relation to the origin of tourist flows on one side, and tourist destinations in the room, on the other hand. This would gradually affirmed, following settlements as phased cells of this type of tourism developments Berane, Andrijevica and Plav. At the same time, however, we should bear in mind the fact that visitors to plan their trips planned movement, and therefore cannot immediately achieve some better results in the extension of tourist stay.

In relation to the recreational use of the available water resources in the northeastern part of Montenegro, value assessment can do in terms of benefits of rowing sports, especially kayak-water. GeoScape has reviewed and hydrographic and physicalgeographical conditions for the development of canoeing and rafting. The development of these activities emphasized almost guaranteed a sufficient quantity of water flowing in Lima, and the average drop in Plav - Murino (total drop $87 \mathrm{~m}$ ), Murino-Andrijevica $(75 \mathrm{~m})$, Andrijevica - Berane $(85 \mathrm{~m})$. At this same profile, i.e. on their initial or neighboring stations, the mean annual flow of water in river Lim the Plav is $17.8 \mathrm{~m}^{3} / \mathrm{s}$ at Berane $37.4 \mathrm{~m}^{3} / \mathrm{s}$ meets the needs of kayaking as a way of sports and recreational activities. As for water, and related, very soft approach, but also very curiosity morphological, floristic and hydrological phenomena that can only be known and experienced through the exercise of the said form of tourist recreation (vertical limestone cliffs, straits, terraces, speleological objects, waterfalls, cascades and karst springs). Thus, the water flows from the mountain northeastern part of Montenegro, which includes Lim (except in the sector through Berane Basin), can be used for kayaking fastest water ( Kasalica,1988).

In relation to the tourist recreational use of the available water resources and valuable assessment of the observed geographic space, and can done in terms of benefits to swim in the rivers. Summer tourism has a distinct feature of the seasonality of the climate, or rather the air temperature. The natural regime of water, the bathing season on rivers and lakes determined by the thermal properties of water and airflow characteristics and morphological characteristics pan. Bathing season can be defined as a period in which the monthly water temperatures above $18^{\circ} \mathrm{C}$, and the mean air temperature over $20^{\circ} \mathrm{C}$. High temperatures in the lake waters last period (July, August and September). When the hydro-climatic complex lake and its immediate surroundings acquire the optimum conditions for the development of spa tourism and that may take place mainly during the two to three months. Conditional temperature limit of $18^{\circ} \mathrm{C}$ cannot be from the perspective of spa tourism in specific cases, be taken as an absolute rule. It cannot, first of all, the locals (Andrijevica, Berane, Plav) relatively well acclimated to the temperature conditions of river water, which corresponds to an average value equal to or greater than $15^{\circ} \mathrm{C}$. Season sea tourism in appropriate recreational spots can last from 30 to 90 days. This fact cannot ignore (especially since formed a belt of sandy beaches along the coast of the river Lima, and has medicinal properties important for the rehabilitation of rheumatic diseases). No matter what it is that 
temperature conditions up to a relatively modest measures conducive to the development of swimming, and therefore the resolution recreational function of coastal population (Kasalica,1988). Flow rate and morphological characteristics of the basin are closely related. During the summer, all the rivers of water are small, so the depth for swimming binds to the concave parts of the bed, especially around the vortices. Here in the value assessment must take into account the accessibility of banks.

However, the main problem in the use of river water for bathing their pollution. For example, cellulose and paper factory was the largest polluter of Lima, which is downstream of Berane grouped in class IV water, or water contaminated through the maximum permissible concentration. The degree of contamination on Lim particularly exacerbated during the period of minimum flow conditions. Desirable changes include progressive leveling discharge, controlled discharge of wastewater and construction of drainage systems with devices for filtering system for continuous monitoring of water quality... This would satisfy the needs of recreation and tourism trends.

To summer tourism developed, it is necessary to combine with mountain tourism. Below average temperatures in the summer months, the northeastern part of Montenegro to provide very favorable natural conditions for vigorous hiking and rock climbing as well as the ever-present all aspects of the development of mountain tourism in general.

Lake considered GeoScape (Plavsko, Ridsko, Visitorsko, Pešić Lake, Big Šiško, Little Šiško, Big Ursulovačko, Little Ursulovačko) its hydrographic characteristics properly emphasize not only the attractiveness of the landscape, but also a functional environment, which can bind the three basic forms of tourism trends inherent in their nature motif (sightseeing, recreation and sport-fishing). Rowing, sailing, kayaking, hiking, underwater sports and fishing are possible on Plavsko Lake and Ridsko. There are also solid conditions for the development of several other sports and recreational activities during the winter season (ice skating, motor skiing...). It was then under the influence of negative temperature values (in proportion to their lake last 3-4 months). The surface layer of the lake water formed ice cover (which the Plavsko Lake takes 30-60 days in winter), which would surface, unless some parts on the surface, should be used as a natural ice rink for practicing these sports and recreational activities in the designated period. Such a determination would have to precede detailed observations and studious appearance, thickness, quality and capacity of ice as hydrological events that occurred during the winter season in most of the studied lakes Geospatial considered ( Kasalica,1988).

Protection from water. In relation to the basic concepts of the text of are protection of water as a separate complex water management problems, corresponding to the treatment of water as a natural condition. The water management practices have successfully developed a number of measures of human resources of water overflow its banks and floodwaters. The current concept of resolution in this part of northeastern Montenegro based mainly on the removal of the most acute problems. Not to access are entire arrangement of individual basins within the catchment. That this is is wrong approach to this problem say torrential flooding.

Examples of catastrophic floods in the northeastern part of Montenegro are numerous. For example, in October 1974 the area of the municipality of Berane during heavy rains carried off the 72 hectares of land, 11 hectares of land were damaged, destroyed 6 bridges on the river Lim (18 on its tributaries, 12 houses and many other natural and material goods). Estimated damages amounted to RSD 735.310 ( Lutovac, 1981).

Note that even seemingly insignificant streams whenever there is any heavy rain made leaved extensive damage, and often in his bosom, and drew people's lives.

In order to alleviate floods and to arable land re-equip for its function, it is necessary in this part of northeastern Montenegro executed: biological, technical and administrative measures. Biological remediation works to the torrent channel: wattle building, raising the horizontal walls, increasing retention ditches, raising the mayor (terrace) and scrape field. Technical work in the riverbed: build cross facilities, service facilities, performed excavation, embankment, building a wall of stone, plaster carburized, build a wall of stone in the dry (without mortar), carried a stone mound, build drainage channels and drainage concrete elements. Administrative measures: deforestation, cutting the trees, excessive use of 
pastures, soil whose slope greater than 15 degrees, place the cottage sprawl on fertile soil (Blagojević, 1998).

To achieve the above, it is necessary to work on educating the population. I need to point out the danger of erosion and degradation and to make farmers Release sloping land. Interested parties should indicate how to prevent construction of the Mayor (terrace), and how to plant orchards in those cities, draw people's attention to cultivation of meadows, forest plantation (type of wood), that cattle raised on those lands (Blagojević, 1998).

The protection against erosion little has done, especially in flood remediation, reforestation, land reclamation of pastures. Made as small anti-erosion measures, but more needed to done especially in the upper, steeper part of the basin. Only erosion in the northeastern part of Montenegro, of the total area of forestland and agricultural, according to Municipal Secretariat of Economy, was attacked about eighty thousand acres. You need to pay attention to unplanned and uncontrolled felling of trees in recent years (egg, cut down the poplar wood Luge as an important resource for the defense of the swollen Lima), which can cause erosion in the activation of this part of the basin.

Floods are the most vulnerable area of alluvial plains in the immediate valley of Lima, with the exception of the sector in the relief flow constriction. The settlements are located at the bottom of the basin, largely affected by floods torrential tributaries, flood wave than Lima. Berane is one of the first municipalities in the northeastern part of Montenegro, which was acceded to solve problems Lima flooding in the urban area with the construction of gabion protection. The construction of a fortress on is coast River Budmlja and Bistrica River (www.beranetown.net).

One of the most important moments of a scientifically based and synchronized operation of all structures determined to work on this issue. The solution to this problem carries a kind of relationship of man and the environment and oneself as land as a primary means of agricultural production cannot replaced by another. It is very important to raise the awareness of people properly about the importance of the situation that exposed only the man whose actions can improve the quality of your life. No one to replace him and will not be done ( Radovanović, 1991).

Water protection. Water protection is one of the bigger problems of water management in the contemporary moment, the socio-economic development. The causal link between use and wastewater discharge is manifold. Ultimately, water pollution leads to depletion of total available water resources. Polluter reliable water in the northeastern part of Montenegro no.

Is catchment vulnerable to surface water and groundwater? Most of them are polluting industry and agriculture - industrial wastewater, sewage, herbicides, pesticides... The biggest polluters are also the largest consumers of water: Tanner "Polimka", "Termovent", "FWI Polimlje", "FWI Pine", "Metal processing" and municipal wastewater urban areas. "Sometimes one of the cleanest European rivers, Lim is now practically landfills. Lim swim huge amounts of different types of waste, since virtually all waste from all the towns through which passes Lim: Plav, Andrijevica, and Berane thrown at... Lim. With hundreds of Lim's sawmill, and sawdust is thrown into the river thereby destroying fish stocks" (www.beranetown.net).

The present results are not comprehensively examines pollution in terms of implications for the development of agriculture and tourism. The situation is even more worrying because it considered the GeoScape sent to the rivers and lakes, as well as hydrographic agricultural and tourist values. Another issue is the protection of groundwater as the main source of water supply of the population. It is necessary to thoroughly examine the area and determine their sanitary-technical security field that includes not only the surface of the collector from which the water is used, but with a collecting area that is the same collector supplied with water. This is the only correct way to hygienic drinking water. Moreover, capping wells often improperly performed the sources not used rationally. In this regard, we should mention the source of "Popče-Petnjica". Analysis sample was determined that are water is bacteriologic ally and chemically documents, but only when there is no rainfall. Specifically, due to poor abstraction done at the source "Popče", the mixing of deep water that makes the water murky and unsafe for drinking.

Protecting the lake is also an urgent need. It must be based on detailed observation and a good range of hydrological parameters, in order that the best security solution. This 
protection implies restraint seats that directly threaten the lake basins affected by denudation, fluvial and karst erosion and hydrophilic vegetation. Thus, for example, under the influence of denudation and fluvial erosion noticeably reduces water area: Pešić Lake, Great and Little Šiško, Great Visitorsko and Little Ursulovačko and Plavsko Lake. Hydrophilic vegetation, surface and volume overwhelmed the great and little Šiško, little Ursulovačko and little Visitorsko. Karst process, more intense coastal and underwater attacks belt Ridsko lake (Stanković, 1996).

The current level of protection of surface and ground waters of the northeastern part of Montenegro is the result of careless man's relation to the environment. Let us show the example of Plavsko Lake. In fact, over the last thirty years, the accumulation of Plavsko Lake is reduced by $12 \%$, or one million cubic meters (now approximately eight million cubic meters), and the lower level of the lake twelve feet (907.2 meters present). This means that for 100 years the Lake will be reduced all the features and physiognomy, and for 200 years, it just turned into a bar, which will flow rivers Ljuča to Lima. It Ljuča its tributaries: Vruje, Dolja and Grnčar, and bring a tremendous amount of material erosion into the lake, thus reducing its useful volume, or his life. Solutions can found in the "Plav Lake - conceptual design of repair and protection from erosion sediment." The concept of the project consists of four parts: stop sediment that reaches Ljuče over the territory of Albania, erosion of torrent control to move Gusinje - Plav, consolidation bed Ljuče in the zone just before the Plav Lake, decorating the basin White streams and riverbeds fixing Lima. The means for rehabilitation and long-term care (1.5 million Euros) are several times lower than the damage to its degradation and loss caused to the northeastern part of Montenegro and beyond. Bearing in mind that the GeoScape discussed its future development builds on the dominant ecologicaleconomic potential, in which the very top, and this gift of nature which is Lake Plav (www.scribd.com).

For all these reasons, it is necessary to take the following forms of protection, not only but also other Plav lake basin through (Stanković,1989):

1. Care which includes a forestation and steep slopes on which they are educated screed and other processes, then, construction of settler everywhere where the lakes are threatened by periodic and permanent tributaries (Ljuča giving water Plavsko Lake),

2. Protection relating to the regulation of all the streams (Lim pointed out at the exit of Plavsko Lake) that intensive erosion regression deepen their beds and remind moraine walls, thus allowing highlighting the growing volumes of water from the lake basin,

3. As at some of these basins do not lose small amounts of water trickling through the moraine apron, this takes the same aprons ask a series of injection curtain that to a large extent, contributed unification water balance of the lake, thus creating favorable conditions for the development of the sport and spa tourism in their area,

4. Since the surface of some lakes threatened and hydrophilic vegetation, it is even more need to save (clearing of vegetation) of this type of threat, which, with all its negative side, noticeably reduces chemical and bacteriological purity water,

5. Since the water that has accumulated, in one of the number of lake basins in danger of extinction, induced, as already mentioned, and a very intense process of karst, it is also, and this process is necessary to restrain hydro technical works done in the field of boring and detailed study of the physical properties of water sinking buildings.

Natural and urban environment are not mutually isolated, despite the impression of their ongoing conflict. More than others, hydrographic objects in this part of northeastern Montenegro, combine and merge different areas of physiognomy, evolution and purpose. Planning one category must not compromise the other. Water intake facilities in the source areas of the river - must not endanger those in the middle and lower reaches. As the river and lake basins impossible to extend, the existing framework is necessary to plan those operations that will not cause disruption of ecological relationships. Protection of rivers and lakes of the northeastern part of Montenegro should not be an end in itself. She has to use the highest possible level of development of society, and therefore the development of agriculture, tourism and recreation. Observed in contemporary society GeoScape needed such rivers and lakes that will serve him in the best possible way. Loopholes in spatial 
planning are necessary to remove in order to save the economy for these premises and location that would meet the interests of the broad market (Stanković, 1989).

\section{INSTEAD OF A CONCLUSION}

It seems that the best results of protection as a basis for evaluation can provide consistent reference to the existing postulates on the water. These must be complementary to understand the principles of the concept of active protection of the environment in which the water is widest matter, the source of life and the condition of its survival. In order to implement the concept of sustainable communities in the northeastern part of Montenegro, that is secure and prevent future devastation of the environment, which produces a risk society, it is necessary to examine the profound transformation of the environment in general. The hardest exam that man starts from the beginning to today, can be successfully overcome and lay solely and only the introduction of quality and excellence for sustainable development (Danelišen et al, 2008). It must not be allowed to present at the threshold of the twenty-first century, mentioned above, one of the most beautiful glacial Lake in the Balkans Plavsko, gets polluted due negligent consequences of man's relation to the environment. Specifically, in the area of lakes there are a number of residential buildings with a population concentrated on agricultural activity, resulting in significant amounts of pollutants in the lake due (organic and inorganic fertilizers, pesticides, sewage households and small farms, water from septic tanks, illegal dumping)(www.scribd.com). In other words, social irresponsibility, gaps in environmental law, urban planning, current relations between man and nature, the lack of seriousness in all forms of environmental awareness, environmental irresponsibility and causing environmental devastation.

Given the foregoing, our research records, based on similar studies (www.gfmo.ba), pointed to the fore several important observations regarding the GeoScape considered:

1. Integrated water resources management in the northeastern part of Montenegro and municipalities Berane, Andrijevica and Plav, must be done in an equitable manner without compromising the sustainability of vital components of organic composition, and to achieve the maximum result of economic and social benefits,

2. It is necessary to harmonize the regulation of the water sector in the northeastern part of Montenegro, in accordance with the principles of the "European Framework Directive". Terms water use prescribed water management document should include the objective of sustainable development,

3. Necessary economic interest in the construction of hydropower plants on the river Lim, respecting the principles of sustainable water resources development and general interest. "The privatization of rivers and lakes, that is, certain parts of their coastal areas must be prevented.......Appearance rivers and lakes, and their coastal areas must be a real expression of social relations" ( Pavić,1979),

4. Possible directions for solving problems of water management, it is necessary to look at the application of the concept of "clean production" with the use of environmentally friendly technologies. With this achieved by continuous application of comprehensive water management strategies, pollution prevention and contribution to sustainable development (Rajović and Bulatović, 2012).

5. Effective monitoring of the quantity and quality of water in the catchment and its tributaries and the lake is a prerequisite to effective water management in the planning phase and in the operational management,

6. Bearing in mind the objective of geo lag considered in terms of technology, which reflected in the water sector, it is necessary to support the introduction of new "tools" in water management, in particular applications based on GIS. This will lead to more efficient water management and decision-making expert in all aspects of water resource management.

7. In relation to the economic situation before 2000 in the area of the catchment is due to the termination or significant reduction of industrial facilities, and reduce the number of inhabitants and their living standards, reduced total water pollution. However, no significant progress in are construction of sewage treatment plants and 
wastewater, which is a water management problem. Surface water and groundwater in Berane, Andrijevica and Plav are threatened many "wild" dump.

8. Lowering of groundwater and surface water, translating water, reducing water influx, is evident in Lima and its tributaries as well as karst springs and wells. It is necessary to conduct a detailed interdisciplinary research in the northeastern part of Montenegro with the aim of collecting data for studies and projects to protect against these adverse effects.

9. Although the waterways are possibilities for the development of recreation and water sports in the direction of contemporary European trends, unless the condition is sporadic examples (Regatta "Cup of Plavsko Lake" competition kayaks, swimming across Lake Plavsko), unsatisfactory and needs to be in the water management basis significantly stimulated.

10. One of the characteristics of the observed geographic space and are unfavorable spatial and temporal distribution of rainfall, which in the rainy part of the year, leading to flood the state with large claims. The average annual rainfall ranges from $863 \mathrm{~mm}$ in Berane, $1.152 \mathrm{~mm}$ in Andrijevica, $1.209 \mathrm{~mm}$ in Plav, $1.351 \mathrm{~mm}$ in Gusinje to 1.698 $\mathrm{mm}$ in Vusanje. Except that the precipitation spatially uneven secrete, their excretion during the year also shows oscillations. Maximum rainfall in January (Berane 132mm, Gusinje -169mm), November (Andrijevica -142 mm, Vusanje - 214mm, Plav $156 \mathrm{~mm}$ ), the main minimum in July (Berane - $50 \mathrm{~mm}$, Andrijevica - 65mm, Plav - 64 $\mathrm{mm}$, Gusinje $-61 \mathrm{~mm}$, Vusanje $-87 \mathrm{~mm}$ ). Thus, annual rainfall decreases towards the North by Berane have two times less than the amount of rainfall Vusanje. The construction of reservoirs space significantly improve degree flood protection and to lessen the effects (Rajović, 2012).

Taking into account are principles of the concept of active protection of our environment, it is possible to sustain Groundwater River and lake waters in the northeastern part of Montenegro and its coastal areas and the catchment as a whole. Complementary to the postulates of the water, the concept of active protection of the environment can applied to the example wholly hydrographic facilities in this part of northeastern Montenegro, which would meet the needs of many users (Krstić,1982). At this point conclusively affirm clearly worded paragraph Vasović and Biočanin (2007): "The present generation should plan and make you the proper quality of the environment, but this right must be retained for the next generate. In accordance with the concept of sustainable development is expected to work culture is based on humane principles ecumenical environmental and social performance. Environmental movement in our society is justified by a compelling necessity, but also an obligation".

\section{REFERENCES}

[1] Rajović G., Bulatović J. (2013), Movement population in the second of XX and beginning of XXI century: The Case northeastern Montenegro, Russian Journal of Agricultural and Socio - Economic Sciences, Volume 1(13):66-79.

[2] Dinić J.(1981), Economic Geography - principles, methods of spatial structure, Faculty of Economics, Belgrade.

[3] Ghosh S. (2011), Protecting natural resources: course of a river movement, Community Developmen Journal, Volume 46 (4): 542-557.

[4] Grafton R. Q., Landry C., Libecap G. D., O'Brien R. J. (2010), Water Markets: Australia's Murray-Darling Basin and the US Southwest, National Bureau of Economic Research.

[5] Boberg J. (2005), Liquid Assets: how demographic changes and water management policies affect freshwater resources, Rand Corporation.

[6] Coelli T., Walding S. (2006), Performance measurement in the Australian water supply industry: A preliminary analysis, Performance measurement and regulation of network utilities.

[7] Covalla E., Pandarinath C., Williams J., Williams J., Wingo A. (2001), Managing Agricultural Water Impacts, North Carolina State University. 
[8] Williams A. M., Shaw,G. (2009), Future play: tourism, recreation and land use, Land Use Policy, Volume 26: 326-335.

[9] Thévenon M. F. (2002), Oils and water repellents in wood protection: Research and development in France, In COST ACTION E 22.

[10] Palanti S., Feci E., Torniai A. M. (2011), Comparison based on field tests of three lowenvironmental-impact wood treatments, International Biodeterioration \& Biodegradation, Volume 65(3): 547-552.

[11] Berane municipality (2010), Official 1, 1 (on-line), Available from: http://www.berane.me (25.09.2012).

[12] Regional Business Centre Berane (2004), Municipal profile Berane, 1, 9.(On-line), Available from: http://www.nasme.me (25.09.2012).

[13] Regional Business Centre Berane (2004), Municipal profile Plav 1, 21-22, Available from: http://www.nasme.me (07.11 2012).

[14] Municipal Andrijevica (2010), Content spatial and urban planning 1, 49-52, Available from: http://www.andrijevica.me (26.09.2012).

[15] Ćirić M. (1991), Pedology, Institute for textbooks and teaching aids, Sarajevo.

[16] Đukanović D.(1967), Air-conditioning district Leskovac, „Nolit“.Belgrade.

[17] Rajović G.(2013 a), Economic- Geographical View of the Flora and Fauna: The Case Northeastern Montenegro, Journal of Sustainable Development Studies, Volume 2 (1): 24-68.

[18] Rajović G.(2005), Geographical basis for the development of the economy of the Upper Polimlja, Printing "Vedes", Belgrade.

[19] Rajović G.(2013b), Economic-Geographical View of the Status and Perspectives of Agricultural North -Eastern Montenegro, Journal of Agriculture and Sustainability, Volume 2 (1):22-42.

[20] Regulation of Lima 1,1.(on-line), Available from: http://www.beranetown.net (27.09.2012).

[21] Kasalica S. (1988), Northern Montenegro, "University word", Nikšić.

[22] Lutovac S.M.(1981), Some examples of environmental degradation in the Upper Polimlje, Annual Geographical Society of Montenegro, Podgorica.

[23] Blagojević M. (1998), Soil degradation in the basin Timok, Journal of Serbian Geographical Society, Number 78: 63-64.

[24] Radovanović M.(1991), The fight against erosion and flood - the most significant water management issues in the basin of Kolubara, Journal of Serbian Geographical Society, Number 71: 37-38.

[25] Stanković M.S.(1996), Theoretical basis of valorization of the lake, Journal of Serbian Geographical Society, Number 76:26-28.

[26] Plavsko Lake 1,1 (on-line), Available from: http://www.scribd.com (27.09.2012).

[27] Stanković M.S.(1989), Travel implications and pollution of surface waters in Serbia, Journal of Serbian Geographical Society, Number 69: 43.

[28] Danelišen D., Aleksić S., Amidžić B., Biočanin R., Rakonjac V.(2008), Medical and ecological importance of diet in the system of quality living environment, Journal Research and Development, Number 28-29: 149.

[29] Scientific symposium (2003), Water in karst basins Cetinje, Neretve i Trebišnjice, Neum: 25-27.06, Available from: http://www.gfmo.ba (28.09.2011).

[30] Pavić R.(1979), Political and spatial aspects of ecological crisis, Journal "Geografica Slovenica", Number 9: 99.

[31] Rajović G., Bulatović J.(2012), Socio economic and geographical factors of development-Study Case: Cities Berana, Andrijevica and Plava, Journal for Geography, Volume 7(1):49-68.

[32] Rajović G.(2012), Climate as the Value of Agricultural of the Example Northeastern Montenegro, American-Eurasian Journal of Agricultural \& Environmental Sciences, Volume 12( 12): 1558-1571.

[33] Krstić B. (1982), Man and space, "Light", Sarajevo.

[34] Vasović V., Biočanin R.(2007), Sustainable Development, Journal Ecologica, Number 49: 68-69. 